\title{
THE EFFECTIVENESS OF AN ACTIVITY-BASED APPROACH TO TEACHING THE PAST TENSE IN MEDICAL ENGLISH FOR PROFESSIONAL PURPOSES
}

\author{
Lysanets Yu.V., Bieliaieva O.M., Znamenska I.V., Morokhovets H.Yu., Rozhenko I.V.
}

Poltava State Medical University,Poltava, Ukraine

The present paper explores the methods for effective mastering the past tense relying on an activity-based approach following the Common European Framework of Reference for Languages. The aim of the research is to facilitate the teaching and revising the grammar material on the past simple (indefinite) tense, the past continuous (progressive) tense, and the past perfect tense in the process of training undergraduates, Ph.D. students, academic and clinical teachers at a medical university. The results of the research have been integrated into the 1st edition of "Medical English for Academic Purposes" (2018) and "Medical English for Public Health Purposes" (2021). The authors developed the methodological mechanisms to support courses in professional English at higher medical educational institutions through an activity-based approach, which ensures the effective acquisition of a foreign language, promotes the formation of a linguistic personality capable not only of communicating in all areas, but also of successful integration into the international community. The paper provides a wide range of scaffolding activities and methods: using visuals (graphic organizers, charts, etc.), selecting historically meaningful texts, peer-to-peer talk, strategic pairings, "real-life tasks" and modelling situations, the "fishbowl" model and others. The suggested methodological algorithm is feasible for both oral and written communication, reading and listening comprehension activities, group work, individual and self-directed work in class, as well as for in-class or self-paced learning, depending on the features of the curriculum and students' English proficiency. The receptive aspect of teaching is represented by read-and-translate exercises, targeted texts describing significant events in the history of medicine, as well as true-false exercises to check students' comprehension. Meanwhile, the reproductive aspect of teaching covers exercises involving opening the brackets, filling the blanks, as well as creating negative and interrogative forms of verbs. Eventually, the productive aspect of teaching is ensured by a wide range of creative speaking and writing activities and "real-life tasks", aimed at developing students' communicative competence in English for Professional Purposes (in-class speaking activities (peer-to-peer talk, class discussion). In addition, collecting family history is yet another pragmatically feasible task to revise and study past tenses. The application of an activitybased approach to teaching the past tenses at a medical university is highly effective to foster essential job-related skills, experience and professional readiness. The authors believe that this, in turn, will promote academic mobility and scientific cooperation, thus contributing to the development of higher medical education in Ukraine, which renders the research relevant.

Keywords: English for Professional Purposes, activity-based approach, the field of knowledge 22 «Health care», the past tense, language teaching mechanisms.

У статті представлено методи формування навичок утворення та вживання граматичної категорії минулого часу на основі діяльнісно-орієнтованого підходу згідно із Загальноєвропейськими Рекомендаціями з мовної освіти в процесі викладання курсу англійської мови за професійним спрямуванням у закладах вищої освіти, які здійснюють підготовку фахівців галузі знань 22 «Охорона здоров'я». Авторами вироблена власна концепція викладу навчального матеріалу з метою оптимізації засвоєння граматичних конструкцій Past Simple, Past Continuous ta Past Perfect. Пропонований підхід апробовано при розробці підручників "Medical English for Academic Purposes" (2018) $i$ "Medical English for Public Health Purposes" (2021). Розроблено лінгводидактичні механізми, спрямовані на розвиток, відпрацювання і систематизацію навичок вживання минулого часу в англійській мові за професійним спрямуванням. Методологічний алгоритм представлений рецептивним, репродуктивним і продуктивним типами вправ і може застосовуватися для вдосконалення різних видів мовленнєвої діяльності, подальшого розвитку як усного, так і писемного мовлення, навичок читання, перекладу й аудіювання, для організації індивідуальної та самостійної роботи здобувачів освіти в аудиторний і позааудиторний час, роботи в малих групах і парах, а також в умовах дистанційного навчання. Обговорено ефективність використання сучасних форм і методів у викладанні англійської мови за професійним спрямуванням: візуалізація навчального матеріалу, робота з оригінальними англомовними текстами, присвяченими найважливішим фактам з історії медицини, навчання за принципом "рівний - рівному", практикоорієнтовані завдання і моделювання професійних ситуацій, метод "Фішбоул" та інші. У висновках зазначається, що застосування діяльнісно-орієнтованого підходу в навчанні англійської мови за професійним спрямуванням у медичному університеті сприяє розвиткові комунікативної компетентності й загальнолінгвістичної грамотності, а також засвоєнню знань і формуванню вмінь і навичок, необхідних у подальшій професійної діяльності фахівця в галузі охорони здоров'я. На думку авторів, такий підхід забезпечить динамізацію процесів академічній мобільності та наукової співпраці на теренах вищої медичної освіти України.

Ключові слова: англійська мова за професійним спрямуванням, діяльнісно-орієнтований підхід, галузь знань 22 «Охорона здоров'я», минулий час, лінгводидактичні механізми.

\footnotetext{
*To cite this English version: Yu.V. Lysanets, O.M. Bieliaieva, I.V. Znamenska, H.Yu. Morokhovets, I.V. Rozhenko The effectiveness of an activity-based approach to teaching the past tense in medical english for professional purposes. // The Medical and ecological problems. - 2021. - Vol 25, № 3-4. - P. 24-27.
} 
The contemporary processes of globalization and European integration are reflected in modern methods of teaching foreign languages, in particular at higher educational institutions of Ukraine [2]. In particular, the new demands of modern society to professional and personal qualities of medical specialists encourage the application of new approaches to teaching foreign languages [6]. Hence, teaching professional English at a medical university requires a pragmatically meaningful context of classroom activities [1; 4]. For this purpose, training material must be naturally embedded in the professionallyoriented resources, thus stipulating an activity-based approach [1; 3]. In such a manner, essential job-related knowledge and skills are fostered, which is the backbone of students' professional readiness. This is particularly relevant for teaching grammar material, such as verb tenses, which must not be separated from a feasible occupational background. An activity-based approach should ensure the effective acquisition of a foreign language, promote the formation of a linguistic personality capable not only of communicating in all areas, but also of successful integration into the international community, as recommended by the Common European Framework of Reference for Languages.

The present paper focuses on the methods for effective mastering the past tense on the basis of an activitybased approach in the process of training undergraduates, Ph.D. students, academic and clinical teachers at a medical university. The results of the research have been integrated into the 1st edition of Medical English for Academic Purposes (2018) and "Medical English for Public
Health Purposes" (2021), which focus on improving the communication skills of medical professionals. We developed the linguo-didactic mechanisms for organizing the training material and delivering the course of Medical English for Professional Purposes. The proposed system of training tasks is intended to support courses in professional English at higher medical educational institutions in teaching and revising the grammar material on the past simple (indefinite) tense, the past continuous (progressive) tense, and the past perfect tense. In this paper, we present excerpts of several sample tasks from our methodological database.

The receptive aspect of teaching is represented by read-and-translate exercises, selected texts describing significant events in the history of medicine, as well as true-false exercises to check students' comprehension. Meanwhile, the reproductive aspect of teaching covers exercises involving opening the brackets, filling the blanks, as well as creating negative and interrogative forms of verbs. Eventually, the productive aspect of teaching is ensured by a wide range of creative speaking and writing activities and "real-life tasks", aimed at developing students' communicative competence in English for Professional Purposes.

The teacher can scaffold communicative skills in many ways. For instance, we suggest using visuals (graphic organizers, charts, etc.). As the first stage of mastering past tenses, students are suggested to revise the specified grammar material by means of relevant illustrative examples from the areas of medicine and healthcare. One of such examples is presented in Fig. 1.

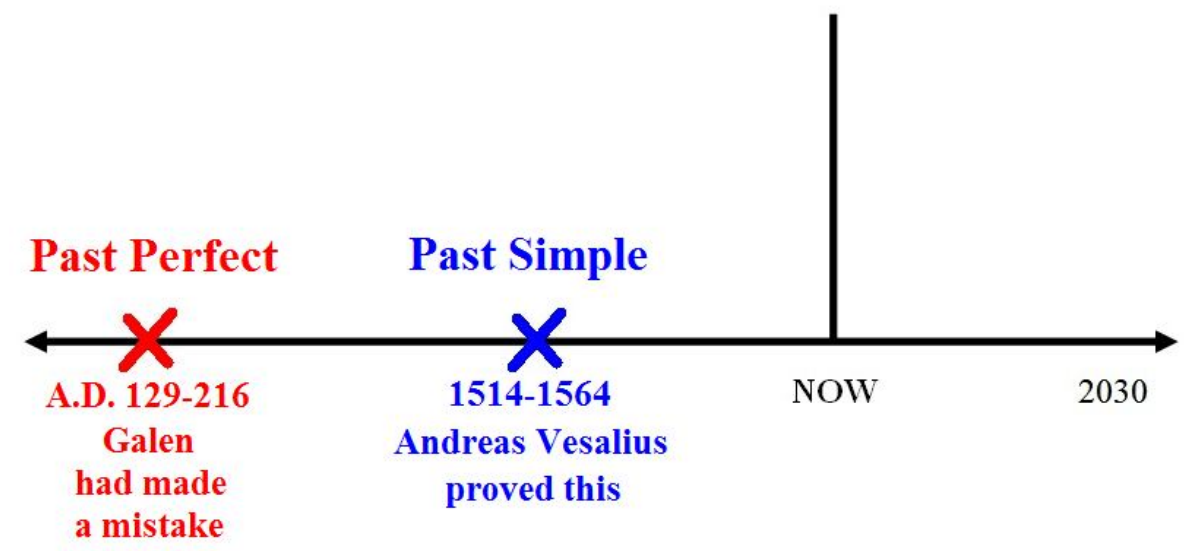

Fig. 1. Visuals for revising the Past Perfect tense.

As one can observe, this figure can be useful in a number of ways. Apart from visualizing the function of Past Perfect, it also serves as a useful resource in terms of the history of medicine thus enriching the general background of students. In addition, it can effectively trigger a broader in-class discussion based on students' previous knowledge of this subject, with a constant focus on the studied grammar material.

Next, students deal with a well-defined set of tasks, gradually covering receptive, reproductive and productive aspects of teaching. The suggested methodological algorithm is feasible for both oral and written communication, as well as for in-class or self-paced learning, depending on the features of the curriculum and students' English proficiency.

Sample tasks:

Ex. 1. Read and translate the sentences (excerpt):

1. The patient forgot to take the antifungal medication yesterday.
2. Did you have measles?

3. The nurse had completed the routine tests before Dr. White came into the ward.

Ex. 2. Read and translate the text. Note the use of Past Simple (excerpt):

BARRY MARSHALL - THE DOCTOR WHO DRANK AN INFECTIOUS BROTH AND SOLVED A MEDICAL MYSTERY

In 2005, Dr. Barry James Marshall (born 30 September 1951) won the Nobel Prize in Medicine together with his long-time collaborator Robin Warren. Their discovery allowed for a breakthrough in understanding a causative link between the bacterium Helicobacter pylori, gastritis and peptic ulcer disease, reversing decades of medical doctrine holding that ulcers were caused by stress, spicy foods, and too much acid. Although medicines like antacids relieved the symptoms, ulcers returned after a patient stopped taking them. Marshall and Warren showed that a 
simple course of antibiotics could cure up to 90 percent of these ulcers.

Ex. 3. Do these statements agree with the information given in Ex. 2? If a statement is false, provide an alternative (excerpt)

1. Marshall proved the link

between, $H$. pylori and liver cirrhosis

2. Dr. Marshall proved that ulcers are caused by stress and poor diet

3. Marshall and Warren shared

the Nobel Prize for their joint discovery the use of Past Perfect:

ANDREAS VESALIUS VS. GALEN (excerpt)

Andreas Vesalius (1515-1564) was a Flemish physician who revolutionised the study of anatomy and changed the way people thought about the human body. Born into a family of physicians and pharmacists, Vesalius began practising medicine at a time when the approach to the human body was based on ancient knowledge passed down from Galen (130-210), a physician who had combined the practice of dissection with his knowledge of Greek philosophers (including Aristotle) to explain the structure of the human body. From the age of 25 , Vesalius set out to prove where Galen had made mistakes. Lecturing in Padua and then Bologna, he set up skeletons of humans and Barbary macaques, and showed the assembled students how wrong Galen had been. Vesalius's suggestion that every student needed to learn from hands-on dissection, and not merely from books and illustrations, was a revolutionary new approach to the study of the body.

As we can observe, these tasks covered the receptive aspect of teaching. For this purpose, we intentionally select historically meaningful texts, encouraging students to discuss significant events in the history of medicine, thereby expanding their professional outlook. These tasks are most suitable for reading and speaking activities, group work in class, as well as self-paced learning.

The didactic purposes of the tasks are as follows: a) revising the use and formation of the past tenses; b) practicing the use of the past simple (indefinite) tense, the past continuous (progressive) tense, and the past perfect tenses; c) developing the reading, translation and listening comprehension skills for professionally-oriented purposes; d) mastering new English medical terms and professional vocabulary to form the past tenses. Moreover, Ex. 2 and 3 provide opportunities for both reading and listening comprehension activities, demonstrating students' understanding of historical facts and relevant grammar material.

Further, students can proceed with reproductive activities. For this purpose, we encourage them to form the correct form of part tenses within the relevant texts, as well as to create negative and interrogative forms of verbs. These tasks are most suitable for writing activities, individual and self-directed work in class, as well as selfpaced learning.

Ex. 5. Put the verb in brackets into the correct form of Past Simple.

ALEXANDER FLEMING'S DISCOVERY OF PENICILLIN (excerpt)

One of the most important medical advances in history (to begin)___ by accident. In 1928, Alexander
Fleming, Professor of Bacteriology at St. Mary's Hospital in London, (to discover)___ penicillin, the world's first antibiotic.

Ex. 6. Put the verb in brackets into the Past Continuous tense:

\section{EXPERIENCE FROM THE FIELD (excerpt)}

(from "A Nurse's Step-By-Step Guide to Transitioning to the Professional Nurse Role" by Cynthia M. Thomas, Constance E. Mclntosh, Jennifer S. Mensi)

It was my fifth day on orientation as a new nurse on a labour-and-delivery unit, when I witnessed a postpartum haemorrhage (PPH) for the first time. I (to shake) as I left the hospital to drive home. All I could think about was the large amount of blood my patient (to lose) after the birth of her first baby.

Ex. 7. Create negative and question versions of these sentences (excerpt):

1. He wrote a report on pathophysiology.

2. The dentist detected signs of periodontal inflammation.

3. The patient broke his scaphoid bone.

The didactic purposes of the tasks are as follows: a) revising the use and formation of the past tenses; b) mastering negative and interrogative forms in the past simple (indefinite) tense, the past continuous (progressive) tense, and the past perfect tenses; c) developing the translation and writing skills for professionallyoriented purposes; d) mastering new English medical terms and professional vocabulary to form the past tenses.

Next, we suggest covering the productive aspect of teaching. In this context, collecting family history is a pragmatically feasible task to revise and study the past tenses.

Ex. 8. Create appropriate questions to match the patient's answers (excerpt):

Doctor: (1)..................... .........................?

Patient: My father died 20 years ago but my mother is 70 and in good health.

Doctor: (2).

Patient: I was still at school. He was 41.

Doctor: (3)... ?

Patient: He had a heart attack.

Hence, students have not only to create questions correctly, but also to deduce the doctor's questions based on the already provided answers. Next, we suggest several in-class speaking activities (peer-to-peer talk, strategic pairings, modelling situations, the "fishbowl" model, class discussion) for Ph.D. students and academic staff:

Ex. 9. Using the Past Simple tense, talk about your previous professional experience. What did you do last year? (a few years ago, last term, etc.)

Ex. 10. Using the Past Continuous tense, ask your partner some special questions about his/her activities from 3 to 5 p.m. (at 10 a.m., etc.) yesterday.

Ex. 11. Write a report about the most significant breakthrough in your specialty. When did it happen? Why was it important? Tell your colleagues about it.

Ex. 12. The image given below displays two consecutive actions in the past. Think of possible events (e.g., from your personal experience) and write down their brief description, using Past Simple and Past Perfect tenses. 


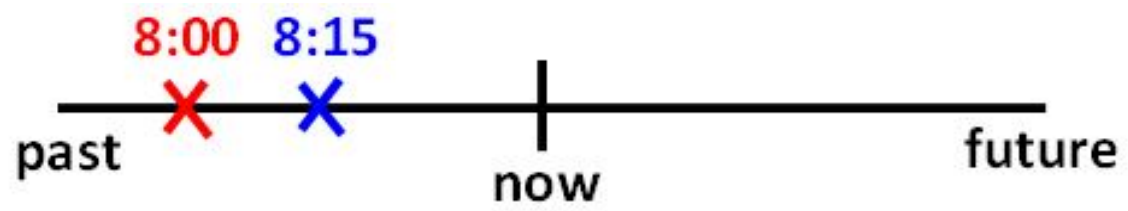

The following model may be of help: "Yesterday, I was late for the meeting. By the time I arrived at 8:15, it $\underline{\text { had }}$ already started".

The didactic purposes of the tasks: a) revising the use and formation of the past tenses; b) practicing the use of the past simple (indefinite) tense, the past continuous (progressive) tense, and the past perfect tense in particular situations; c) developing the speaking skills for professionally-oriented purposes; d) mastering new English medical terms and professional vocabulary to form the past tenses.

Thus, an activity-based approach makes it possible to identify the social context of an individual's functioning in the particular field of knowledge, to give concrete expression to linguistic material, the type of speech situations and, accordingly, to highlight the types of speaking activities necessary for the successful work and life in the modern society, as well as to determine the acquired level of language proficiency. The application of this approach to teaching the past tenses at a medical university is highly effective to foster essential job-related skills, experience and professional readiness. The authors believe that this, in turn, will promote academic mobility and scientific cooperation, thus contributing to the development of higher medical education in Ukraine, which renders the research relevant.

\section{References}

1. Bieliaieva O.M. Funktsional'no-zmistovni ta funktsional'nostyl'ovi kharakterystyky naukovykh tekstiv. Innovatsiyi v osviti, nautsi ta vyrobnytstvi: materialy shostoyi Vseukr. konf. 2009: 108-110.

2. Zuyenok I. Diyal'nisnyy pidkhid do vyvchennya inozemnykh mov za profesiynym spryamuvannyam. Suchasni pidkhody ta innovatsiyni tendentsiyi u vykladanni inozemnykh mov. Materialy VII Mizhnarodnoyi naukovopraktychnoyi konferentsiyi. 2012: 72-74.

3. Labenko O. A. Diyal'nisno-oriyentovanyy pidkhid do vyvchennya inozemnoyi movy u konteksti yevrointehratsiynykh protsesiv. Problemy semantyky, prahmatyky ta kohnityvnoyi linhvistyky. 2010; 18: 233-240.

4. Maksymenko O. Pidkhody do profesiyno-oriyentovanoho navchannya inozemnykh mov u yevropeys'kiy inshomovniy osviti. Porivnyal'no-pedahohichni studiyi. 2015: 81-86.

5. Lysanets Yu., Bieliaieva O., Melaschenko M. Medical English for Academic Purposes. 2018: 312.

6. Robinson A., Lysanets Yu., Bieliaieva O. Implementation of the Integrative Approach to Teaching Medical English for Academic Purposes. Aktual'ni pytannya linhvistyky, profesiynoyi linhvodydaktyky, psykholohiyi i pedahohiky vyshchoyi shkoly: Zbirnyk statey III Mizhnarodnoyi nauk.prakt. konf. 2018: 273-281.

Матеріал надійшов до редакції 07.05.2021 